\title{
Current status of African swine fever virus in a population of wild boar in eastern Poland (2014-2015)
}

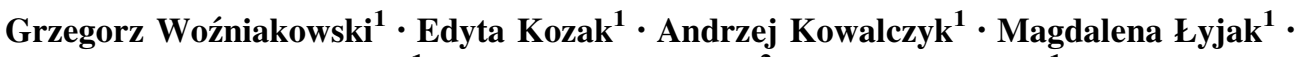 \\ Małgorzata Pomorska-Mól ${ }^{1} \cdot$ Krzysztof Niemczuk $^{2} \cdot$ Zygmunt Pejsak $^{1}$
}

Received: 26 June 2015/ Accepted: 14 October 2015/Published online: 26 October 2015

(C) The Author(s) 2015. This article is published with open access at Springerlink.com

\begin{abstract}
African swine fever virus (ASFV) was detected in wild boar in eastern Poland in early 2014. So far, 65 cases of ASFV infection in wild boar have been recognised. The methods used for ASFV detection included highly specific real-time PCR with a universal probe library (UPL), enzyme-linked immunosorbent assay (ELISA), and an immunoperoxidase test (IPT) for identification of anti-ASFV antibodies. The positive ASF cases were located near the border with Belarus in Sokółka and Białystok counties. Some of the countermeasures for disease prevention include early ASF diagnosis by ASFV DNA identification as well as detection of specific antibodies by systematic screening. The aim of this study was to assess the current ASF status in a Polish population of wild boar during the last two years (2014-2015).
\end{abstract}

Keywords African swine fever virus - Epidemiology · Diagnosis · Wild boar

African swine fever (ASF) is a contagious viral disease affecting swine, wild boar, warthogs, and other hosts belonging to family Suidae [2, 4, 5, 7, 16, 19]. The disease is caused by African swine fever virus (ASFV), the sole member of the family Asfarviridae. ASF is a notifiable disease that seriously affects local and international trade of swine and processed meat products [19, 21]. ASF was first diagnosed in Europe (Portugal) at the end of 1950. The

Grzegorz Woźniakowski

grzegorz.wozniakowski@piwet.pulawy.pl

1 Department of Swine Diseases, National Veterinary Research Institute, Partyzantów 57 Avenue, 24-100 Puławy, Poland

2 National Veterinary Research Institute, Partyzantów 57 Avenue, 24-100 Puławy, Poland disease was then found in Malta, Italy, France, Belgium and the Netherlands [2, 5, 6, 9-13]. Due to successful biosecurity regulations, African swine fever virus (ASFV) was then eradicated from most European regions at the beginning of 1990. However, it still remains endemic in Sardinia and sub-Saharan Africa [10, 11, 22]. African swine fever (ASF) became exceptional in 2007, when the virus reached Poti docks in Georgia with contaminated feed for pigs [13-16, 20]. This event has irreversibly affected the international trade of pig meat. ASF was then identified in Armenia, Azerbaijan, and the Caucasus region of the Russian Federation (RF) [12, 14]. Subsequently, the virus spread to Belarus, Ukraine, Estonia, Latvia and Lithuania [12, 20-22]. In Poland, ASFV was detected for the first time in February 2014 in dead wild boar in Sokółka county $[17,18]$. Previously, we described the ASF epidemiological situation in August 2014 and described 14 cases and two outbreaks in pigs. However, the virus continued to spread among wild boar within Sokółka and Białystok counties, with two peaks of infection in July and August and in November and December [18]. Since there is not a commercially available vaccine against ASF, one of the most important measures for disease prevention is control of wild boar reproduction. However, even if a vaccine were available, it might be used only for domestic pigs and not wild boars. Additionally, pigs from smallscale holdings are prone to come in contact with potentially infected wild boars due to low-biosecurity conditions [17, 18]. There are very few diseases for which vaccines are used in wild animals. Also, the diagnosis of ASF is exceptionally important to control the spread of infection among populations of wild boar and pigs. Therefore, the role of the National Reference Laboratory (NRL) for diagnosis of ASF seems to be essential to cope with the current situation caused by this devastating disease of wild 
boars and pigs. The methods applied by the NRL include real-time PCR with application of a universal probe library (UPL), enzyme-linked immunosorbent assay (ELISA), and an immunoperoxidase test (IPT) for anti-ASFV identification of antibodies. Further genotyping using p72 gene sequencing may also provide additional information about the genotypes of ASFV isolates [3,9]. It is important to emphasize that viral DNA may only be detected during acute infection of wild boar and swine. The DNA concentration may be high among animals suffering from acute infection or in carcasses of animals that died of acute ASF $[8,16]$. Viremic animals suffering from acute ASF are frequently negative for antibodies by either ELISA or IPT for a period of time. These animals require at least 7-10 days from the time of infection to develop an antibody immune response that is detectable by ELISA or IPT [16]. The aim of this study was to summarise the current status of ASFV in a population of wild boar in Poland for the last 17 months since the first diagnosed case.

All stages of processing and sample preparation for diagnosis of ASF were performed in a biosafety level 3 laboratory (BSL-3) by qualified staff and supervisors. The standard Ba71V strain with a titer of $10^{8} 50 \%$ hemadsorption units $\left(\mathrm{HADU}_{50}\right)$ was used as a positive control. It was kindly provided by the European Union Reference Laboratory (URL) for ASF (CISA-INIA, Valdeolmos, Spain). Until June 17, 2015 (starting from January 1, 2014), a total of 29,533 samples of blood, internal organs (spleen, lungs, kidneys, tonsils and bone marrow) from hunted or dead wild boar (Sus scrofa) were collected, corresponding to 22,095 individual animals. The samples were sent to the NRL for ASF at the NVRI, Pulawy, Poland, for ASFV monitoring. The sections of tissues were processed as 10 $(\mathrm{w} / \mathrm{v})$ homogenates in phosphate-buffered saline (PBS) and then used for DNA extraction. Blood clots from dead wild boar were used to obtain serum samples, which were prepared as 1:2 or 1:80 dilutions and then examined by ELISA and IPT, respectively.

Total DNA was extracted from $200-\mu \mathrm{L}$ samples from infected cell culture, peripheral blood or tissue homogenates using a High Pure PCR Template Preparation Kit, following the manufacturer's procedure (Roche Diagnostics, Basel, Switzerland). The final elution was done with $50 \mu \mathrm{L}$ of sterile nuclease-free water. The extracted DNA was stored at $-20{ }^{\circ} \mathrm{C}$ until further analysis.

Real-time PCR with an UPL was conducted in eight 0.2$\mathrm{ml}$ optical tubes in an MX3005P real-time PCR system (Stratagene, Agilent Technologies Inc., Santa Clara, CA, USA). The primers ASF-VP72-F and ASF-VP72-R and probe UPL\#162 used for this method were complementary to the conserved VP72 sequence region of ASFV. The primer sequences and reaction conditions were consistent with the previously described protocol [8]. Briefly, real- time PCR was conducted using a LightCycler 480 Probes Master kit (Roche Applied Science, Basel, Switzerland) in a final volume of $20 \mu \mathrm{L}$. The reaction mixture contained 1x-concentrated LC480 Probes Master PCR Mix, $0.4 \mu \mathrm{M}$ each ASF-VP72-F and ASF-VP72-R primer and $0.1 \mu \mathrm{M}$ UPL\#162 probe. The thermal programme was as follows: 5 min at $95{ }^{\circ} \mathrm{C}$ (initial denaturation), followed by 40 cycles at $95{ }^{\circ} \mathrm{C}$ for $10 \mathrm{~s}$ (exact denaturation) and $60{ }^{\circ} \mathrm{C}$ for $30 \mathrm{~s}$ (primer annealing and PCR product elongation). The fluorescence signal was collected during the primer-annealing and elongation step of each cycle using the FAM channel (excitation $\lambda=495 \mathrm{~nm}$, emission $\lambda=520 \mathrm{~nm}$ ). A fluorescent curve with a threshold cycle value $(\mathrm{Ct})$ lower than 38 was considered a positive result.

Enzyme-linked immunosorbent assay (ELISA) was conducted to detect specific anti-ASFV antibodies in sera collected from wild boar. The antibodies were detected using an Ingezim PPA Compac 1.1.PPA K3 ELISA Kit (Ingenasa, Madrid, Spain). The assay was assumed to be valid if the optical density (OD) ratio of the negative control $\left(\mathrm{N}_{\mathrm{c}}\right)$ to the positive control $\left(\mathrm{P}_{\mathrm{c}}\right)$ was equal to or greater than 4 . The positive cutoff was calculated as $N_{c}$ $\left(\mathrm{N}_{\mathrm{c}}-\mathrm{P}_{\mathrm{c}}\right) \times 0.5$, while the negative cut off was calculated as $\mathrm{N}_{\mathrm{c}}-\left(\mathrm{N}_{\mathrm{c}}-\mathrm{P}_{\mathrm{c}}\right) \times 0.4$. The serum samples were considered positive if the average of their OD values was lower than the positive cutoff. The samples were considered negative if the average OD was higher than the negative cutoff. The sera that were considered doubtful had an average OD between the calculated positive and negative cutoff values. In general, the $\mathrm{P}_{\mathrm{c}}$ value reached $\sim 0.1 \pm 0.02$, while $\mathrm{Nc}$ reached $\sim 1.4 \pm 0.03$. The declared sensitivity and specificity of this ELISA were between $95 \%$ and $98 \%$.

The IPT was conducted using fixed Vero cells infected with Ba71V ASFV in 96-well plates as described elsewhere [10].

The results obtained for positive ASFV cases were compared to the total number of wild boar examined in 2014 and 2015 and analyzed using a two-tailed difference test. The significance level was $\alpha=0.05$. Calculations were made in Microsoft Excel ver. 2007 (Microsoft, Redmond, Washington, USA).

All 65 diagnosed ASFV cases were located near the Belarusian border in Podlaskie voivodeship within Białystok and Sokólka counties. The case that was most distant from the border was C58, located close to the town of Krukowszczyzna (Fig. 2A, Table 1). The distances for particular cases are shown in Fig. 2A. On the February 14, 2014, the first case was reported in dead wild boar from the town of Grzybowszczyzna in Sokólka County (Fig. 1, Table 1). The $\mathrm{C}_{\mathrm{T}}$ value obtained with homogenates of liver and lungs was $30.63 \pm 0.09$. Due to the sample type, it was not possible to perform serological assays (ELISA and 
Table 1 Positive results for samples collected from wild boar (cases) between 2014 and 2015 using real-time PCR UPL, ELISA and IPT assays

\begin{tabular}{|c|c|c|c|c|c|c|c|}
\hline $\begin{array}{l}\text { Case } \\
(\mathrm{C}) / \\
\text { number }\end{array}$ & $\begin{array}{l}\text { Location (nearest } \\
\text { town) }\end{array}$ & $\begin{array}{l}\text { Location } \\
\text { (county) }\end{array}$ & $\begin{array}{l}\text { Collection } \\
\text { date }\end{array}$ & $\begin{array}{l}\text { Sample origin (D-dead, } \\
\text { H-hunted wild boar)/tissue }\end{array}$ & $\begin{array}{l}\text { Mean real-time PCR cycle } \\
\text { threshold value }\left(\mathrm{C}_{\mathrm{T}}\right) \pm \mathrm{SD}\end{array}$ & $\begin{array}{l}\text { ELISA result/ } \\
\mathrm{OD} \pm \mathrm{SD}\end{array}$ & $\begin{array}{l}\text { IPT } \\
\text { result }\end{array}$ \\
\hline $\mathrm{C} 1$ & Grzybowszczyzna & Sokółka & 18.02 .2014 & D/bone & $30.63 \pm 0.09$ & N/A & N/A \\
\hline $\mathrm{C} 2$ & Ozierany Wielkie & Sokółka & 25.03 .2014 & D/blood and lung & $25.12 \pm 8.22$ & $\begin{array}{l}+/ \\
\quad(0.81 \pm 0.00)\end{array}$ & - \\
\hline C3 & Rudaki & Sokółka & 19.05 .2014 & D/blood and spleen & $27.45 \pm 5.11$ & $\begin{array}{l}+/-/ \\
(1.15 \pm 0.00)\end{array}$ & N/A \\
\hline $\mathrm{C} 4$ & Łosiniany & Sokółka & 29.05 .2014 & D/blood and lung & $22.49 \pm 0.23$ & $\begin{array}{l}+/ \\
\quad(0.96 \pm 0.00)\end{array}$ & N/A \\
\hline C5 & Słoja & Sokółka & 24.06 .2014 & D/spleen & $24.46 \pm 3.20$ & N/A & N/A \\
\hline C6 & Bobrowniki & Białystok & 30.06 .2014 & D/blood and spleen & $27.66 \pm 4.54$ & $+{ }^{+/}(0.52 \pm 0.00)$ & + \\
\hline $\mathrm{C} 7$ & Łużany & Białystok & 04.07 .2014 & D/bone & $28.44 \pm 0.00$ & N/A & N/A \\
\hline $\mathrm{C} 8$ & Wiejki/Zubry & Białystok & 08.07 .2014 & D/bone & $28.32 \pm 0.00$ & N/A & N/A \\
\hline C9 & Skroblaki & Białystok & 15.07 .2014 & D/bone & $30.35 \pm 0.00$ & N/A & N/A \\
\hline $\mathrm{C} 10$ & Gródek-Wiejki & Białystok & 29.07 .2014 & D/bone & $25.28 \pm 0.00$ & N/A & N/A \\
\hline C11 & $\begin{array}{l}\text { Jałówka- } \\
\text { Łupianka Nowa }\end{array}$ & Białystok & 29.07 .2014 & D/bone & $22.72 \pm 0.00$ & N/A & N/A \\
\hline $\mathrm{C} 12$ & Wiejki-Zubry & Białystok & 30.07 .2014 & $\mathrm{D} / \mathrm{blood}$ and spleen & $21.42 \pm 2.12$ & - & - \\
\hline $\mathrm{C} 13$ & Horczaki Górne & Białystok & 21.08 .2014 & $\mathrm{D} / \mathrm{blood}$ and spleen & $28.93 \pm 5.61$ & - & - \\
\hline $\mathrm{C} 14$ & $\begin{array}{l}\text { Kolonia } \\
\text { Mostowlany }\end{array}$ & Sokółka & 24.08 .2014 & D/spleen and kidney & $25.55 \pm 1.18$ & N/A & N/A \\
\hline $\mathrm{C} 15$ & $\begin{array}{r}\text { Zaleszany } \\
\text { Kolonia }\end{array}$ & Białystok & 12.09 .2014 & D/spleen and kidney & $22.55 \pm 0.00$ & N/A & N/A \\
\hline C16 & Straszewo & Białystok & 22.09 .2014 & H/blood & $22.26 \pm 0.00$ & - & - \\
\hline $\mathrm{C} 17$ & $\begin{array}{c}\text { Nowosady } \\
\text { Kolonia }\end{array}$ & Białystok & 04.10 .2014 & D/blood and kidney & $23.56 \pm 1.84$ & - & - \\
\hline $\mathrm{C} 18$ & Pieszczaniki & Białystok & 07.10 .2014 & D/blood & $27.07 \pm 3.51$ & - & - \\
\hline C19 & Wyżary & Białystok & 20.10 .2014 & D/bone & $20.83 \pm 0.00$ & N/A & N/A \\
\hline $\mathrm{C} 20$ & Zaleszany & Białystok & 11.11 .2014 & H/blood & $38.50 \pm 0.00$ & $+\stackrel{+/}{(0.88 \pm 0.01)}$ & + \\
\hline $\mathrm{C} 21$ & Wiejki & Białystok & 21.11 .2014 & $\mathrm{D} / \mathrm{blood}$ and spleen & $20.57 \pm 1.32$ & - & - \\
\hline $\mathrm{C} 22$ & $\begin{array}{l}\text { Ostrów } \\
\text { Południowy/ } \\
\text { Górany }\end{array}$ & Białystok & 24.11.2014 & H/blood & $24.89 \pm 0.00$ & - & - \\
\hline $\mathrm{C} 23$ & Mieleszki & Białystok & 30.11 .2014 & H/blood & $32.17 \pm 0.00$ & $\begin{array}{l}+/ \\
\quad(1.03 \pm 0.00)\end{array}$ & + \\
\hline $\mathrm{C} 24$ & Piłatowszczyzna & Sokółka & 30.11 .2014 & H/lung & $33.20 \pm 0.00$ & N/A & N/A \\
\hline $\mathrm{C} 25$ & Podłaźnisko & Białystok & 02.12 .2014 & D/spleen and kidney & $20.73 \pm 2.40$ & N/A & N/A \\
\hline $\mathrm{C} 26$ & Mostowlany & Sokółka & 05.12 .2014 & H/blood & $40.00 \pm 0.00$ & $\begin{array}{l}+/ \\
\quad(0.31 \pm 0.00)\end{array}$ & + \\
\hline $\mathrm{C} 27$ & Piłatowszczyzna & Białystok & 06.12 .2014 & $\mathrm{H} /$ blood and lung & $25.33 \pm 0.00$ & - & - \\
\hline $\mathrm{C} 28$ & Nowosady & Sokółka & 06.12 .2014 & H/lung & $34.09 \pm 0.00$ & N/A & N/A \\
\hline $\mathrm{C} 29$ & $\begin{array}{l}\text { Grzybowce/ } \\
\text { Skroblaki }\end{array}$ & Białystok & 06.12 .2014 & $\mathrm{H} /$ lung & $25.06 \pm 0.38$ & N/A & N/A \\
\hline C30 & Podłaźnisko & Białystok & 23.12 .2014 & $\begin{array}{l}\text { D/blood, liver, spleen and } \\
\text { kidney }\end{array}$ & $21.86 \pm 0.00$ & - & \\
\hline C31 & Radunin & Białystok & 16.01 .2015 & D/spleen & $17.64 \pm 0.00$ & N/A & N/A \\
\hline C32 & Zadworzany & Sokółka & 02.02 .2015 & D/blood, spleen kidney & $26.53 \pm 7.50$ & - & - \\
\hline C33 & Piłatowszczyzna & Sokółka & 29.01 .2015 & H/blood, and spleen & $24.00 \pm 0.00$ & - & - \\
\hline C34 & Cisówka & Sokółka & 03.02 .2015 & D/kidney & $24.45 \pm 0.00$ & N/A & N/A \\
\hline C35 & Budy & Białystok & 05.02 .2015 & D/spleen & $26.21 \pm 5.20$ & N/A & N/A \\
\hline
\end{tabular}


Table 1 continued

\begin{tabular}{|c|c|c|c|c|c|c|c|}
\hline $\begin{array}{l}\text { Case } \\
(\mathrm{C}) / \\
\text { number }\end{array}$ & $\begin{array}{l}\text { Location (nearest } \\
\text { town) }\end{array}$ & $\begin{array}{l}\text { Location } \\
\text { (county) }\end{array}$ & $\begin{array}{l}\text { Collection } \\
\text { date }\end{array}$ & $\begin{array}{l}\text { Sample origin (D-dead, } \\
\text { H-hunted wild boar)/tissue }\end{array}$ & $\begin{array}{l}\text { Mean real-time } P C R \text { cycle } \\
\text { threshold value }\left(C_{T}\right) \pm S D\end{array}$ & $\begin{array}{l}\text { ELISA result/ } \\
\mathrm{OD} \pm \mathrm{SD}\end{array}$ & $\begin{array}{l}\text { IPT } \\
\text { result }\end{array}$ \\
\hline $\mathrm{C} 36$ & Wierzchlesie & Białystok & 13.02 .2015 & D/bone & $29.86 \pm 0.00$ & N/A & N/A \\
\hline $\mathrm{C} 37$ & Bielewicze & Białystok & 15.02 .2015 & D/bone & $36.28 \pm 0.00$ & N/A & N/A \\
\hline $\mathrm{C} 38$ & Kondratki & Sokółka & 16.02 .2015 & D/bone & $31.46 \pm 0.00$ & N/A & N/A \\
\hline C39 & Kolonia Bachury & Białystok & 02.03 .2015 & D/bone & $27.86 \pm 0.00$ & N/A & N/A \\
\hline $\mathrm{C} 40$ & Kondratki & Białystok & 07.03 .2015 & D/spleen & $21.45 \pm 0.00$ & N/A & N/A \\
\hline C41 & Majdan & Białystok & 10.03.2015 & D/spleen and kidney & $24.59 \pm 0.00$ & N/A & N/A \\
\hline $\mathrm{C} 42$ & Bielewicze & Białystok & 15.03 .2015 & D/blood and spleen & $24.52 \pm 1.77$ & $\begin{array}{l}+/ \\
\quad(0.85 \pm 0.01)\end{array}$ & + \\
\hline $\mathrm{C} 43$ & Narewka & Hajnowka & 19.03.2015 & D/blood and spleen & $27.93 \pm 6.31$ & - & - \\
\hline $\mathrm{C} 44$ & Kolonia Cisówka & Białystok & 25.03 .2015 & D/bone & $30.80 \pm 2.70$ & N/A & N/A \\
\hline C45 & Biały Ług & Skololka & 25.03.2015 & D/blood, spleen, tonsils & $24.48 \pm 2.49$ & $\begin{array}{l}+/-/ \\
\quad(1.15 \pm 0.00)\end{array}$ & - \\
\hline $\mathrm{C} 46$ & Kolonia Cisowka & Białystok & 30.03 .2015 & D/spleen & $21.37 \pm 0.00$ & N/A & N/A \\
\hline $\mathrm{C} 47$ & Bielewicze & Białystok & 30.03 .2015 & D/lung & $30.62 \pm 2.58$ & N/A & N/A \\
\hline $\mathrm{C} 48$ & Straszewo & Białystok & 1.04 .2015 & D/bone & $26.20 \pm 0.00$ & N/A & N/A \\
\hline C49 & Cisowka & Białystok & 02.04 .2015 & D/bone & $29.71 \pm 0.00$ & N/A & N/A \\
\hline $\mathrm{C} 50$ & Kruglany & Sokółka & 05.04 .2015 & D/blood, spleen and kidney & $26.32 \pm 0.00$ & - & N/A \\
\hline C51 & Straszewo & Białystok & 09.04 .2015 & D/bone & $37.74 \pm 0.00$ & N/A & N/A \\
\hline C52 & Wierzchlesie & Sokółka & 10.04 .2015 & $\mathrm{D} /$ spleen and tonsils & $23.36 \pm 0.00$ & N/A & N/A \\
\hline C53 & Puciłki & Sokółka & 11.04.2015 & D/blood, spleen and tonsils & $25.30 \pm 0.00$ & - & N/A \\
\hline C54 & Borsukowizna & Sokółka & 14.04 .2015 & D/spleen and tonsils & $38.60 \pm 0.00$ & N/A & N/A \\
\hline C55 & Straszewo & Białystok & 15.04 .2015 & D/tonsils & $26.52 \pm 0.80$ & N/A & N/A \\
\hline C56 & Juszkowy Gród & Białystok & 16.04 .2015 & H/blood & $34.90 \pm 0.00$ & $+{ }^{+l}(0.26 \pm 0.00)$ & + \\
\hline C57 & $\begin{array}{l}\text { Kolonia } \\
\text { Mieleszki }\end{array}$ & Białystok & 18.04 .2015 & H/blood & $32.14 \pm 0.19$ & $\stackrel{+l}{(0.11 \pm 0.00)}$ & + \\
\hline $\mathrm{C} 58$ & Krukowszczyzna & Białystok & 27.04.2015 & D/spleen and kidney & $26.94 \pm 0.00$ & N/A & N/A \\
\hline C59 & Łaźnisko & Sokółka & 08.05 .2015 & D/spleen and kidney & $24.02 \pm 0.82$ & N/A & N/A \\
\hline C60 & Dzierniakowo & Białystok & 13.05 .2015 & D/lung & $23.44 \pm 0.83$ & N/A & N/A \\
\hline C61 & Nowosady & Białystok & 20.05.2015 & D/spleen & $23.02 \pm 0.04$ & N/A & N/A \\
\hline C62 & Nowe Trzciano & Sokółka & 21.05.2015 & D/blood and spleen & $27.23 \pm 0.00$ & - & N/A \\
\hline C63 & Cisówka & Białystok & 22.05 .2015 & D/bone & $34.61 \pm 0.00$ & N/A & N/A \\
\hline C64 & Planty & Białystok & 1.06 .2015 & D/bone & $29.30 \pm 3.05$ & N/A & N/A \\
\hline C65 & Dzierniakowo & Białystok & 2.06 .2015 & D/bone & $25.12 \pm 0.00$ & N/A & N/A \\
\hline
\end{tabular}

The case number, origin of each sample, localization, collection date and mean cycle threshold $\left(\mathrm{C}_{\mathrm{T}}\right)$ values with standard deviation $(\mathrm{SD})$ are given. The ELISA results expressed as optical density (OD) are given. The ELISA and IPT results are provided where applicable. N/A, not applicable; SD, standard deviation. The sera originating from dead wild boar were retrieved from blood clots

IPT). Next, four cases in wild boar (C2, C3, C4, C5) were identified within the same county. The $\mathrm{C}_{\mathrm{T}}$ values obtained with these samples collected from affected animals ranged from $22.49 \pm 0.23$ in a wild boar from the town of Łosiniany (C4) to $27.45 \pm 5.11$ in samples collected in Rudaki (C3) (Table 1, Figs. 1 and 2). The presence of antiASFV antibodies was detected in blood of wild boar from $\mathrm{C} 2(\mathrm{OD}=0.81 \pm 0.00)$ and $\mathrm{C} 4(\mathrm{OD}=0.96 \pm 0.00)$. These cases were noted between February and the end of June 2014. At the same time, C6 was diagnosed in wild boar from Bobrowniki in Sokółka County (Table 1). The presence of specific anti-ASFV antibodies in the blood of wild boar from C6 was confirmed by ELISA $(\mathrm{OD}=0.52 \pm 0.00)$ and IPT. In the period between July and August, eight new cases (C7-C14) were identified. These were located mainly in Białystok (C7-C12, C14) and Sokółka counties (C11, C13) (Fig.1, Table 1). The observed $\mathrm{C}_{\mathrm{T}}$ values from $\mathrm{C} 7, \mathrm{C} 8$ and $\mathrm{C} 9$ ranged from $28.44 \pm 0.00$ (C8) to $30.35 \pm 0.00$ (C9) in the samples from carcasses found in Skroblaki, Łużany and Wiejki/ 
Fig. 1 Localisation of ASFVpositive animals. Blue, ASF risk area; yellow, protected area; red, restricted area; blue + red, infected area. The map originates from the resources of the General Veterinary Inspectorate, Warsaw, Poland. (color figure online)

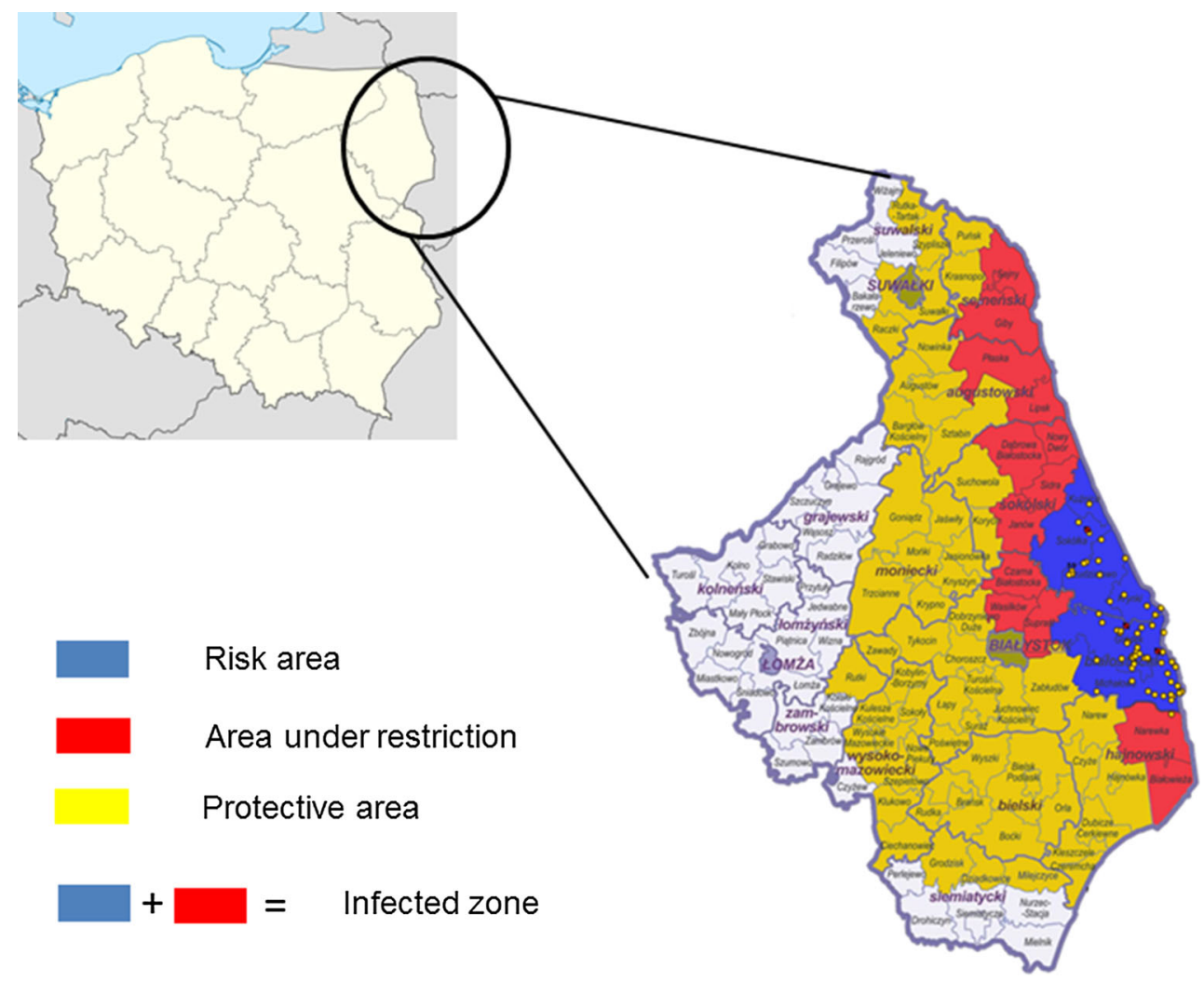

(A)

Fig. 2 Distance of ASFV positive animals from the Belarusian border (A) and comparison of mean cycle threshold values $\left(\mathrm{C}_{\mathrm{T}}\right)$ from particular cases (B). The graph shows the relative DNA concentration is samples collected from particular cases and outbreaks of ASFV. The $\mathrm{C}_{\mathrm{T}}$ value for $\mathrm{C} 26$ reached 40.00 and is absent from the graph. The localization of particular cases shows a negative correlation between distance and transfer of ASFV infection

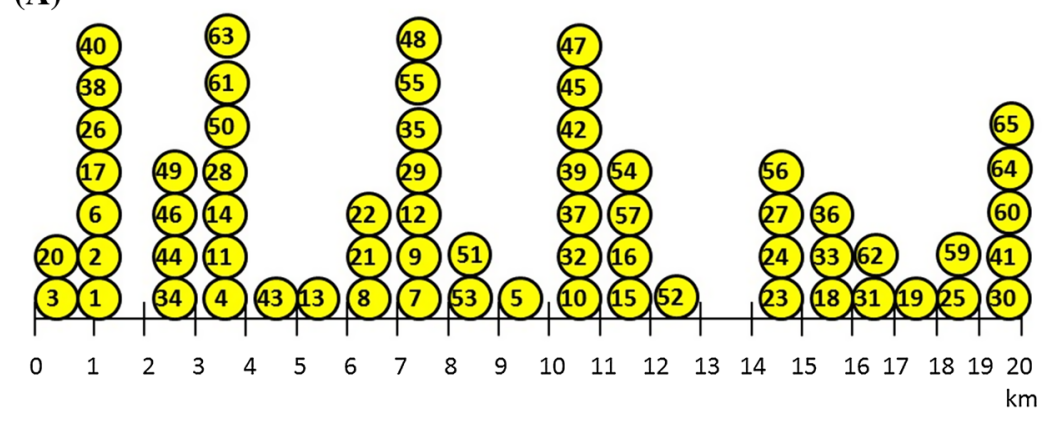

(B)

Relative virus concentration (40-Ct)

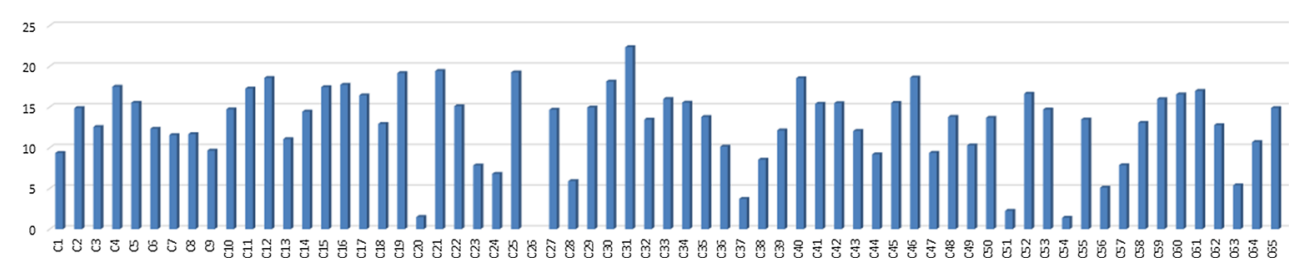


Zubry (Table 1, Fig. 2B). These values were considerably lower than those obtained from $\mathrm{C} 10-\mathrm{C} 14$. The mean $\mathrm{C}_{\mathrm{T}}$ values are showed in Fig. 2B to present the relative concentration of viral DNA in particular cases. In the time period from September 2014 to December 2014, 16 new cases (C15-C30) were identified within Białystok and Sokółka counties. The observed mean $\mathrm{C}_{\mathrm{T}}$ values ranged from $20.57 \pm 1.32(\mathrm{C} 21)$ to $38.5 \pm 0.00(\mathrm{C} 20)$. Further analysis of these case by ELISA showed the presence of specific antibodies in wild boar blood collected from $\mathrm{C} 20$ $(0.88 \pm 0.01), \mathrm{C} 23(1.03 \pm 0.00)$ and C26 $(0.31 \pm 0.00)$. In other investigated cases, specific antibodies were not detected. The beginning of January 2015 brought new ASF cases (C31) located in Raduin in Białystok County. Between February and June 2015, 33 new ASFV cases (C32-C65) were identified in hunted or dead wild boar from Białystok and Sokólka counties, but case C43 was confirmed for the first time in Hajnówka district, $4 \mathrm{~km}$ from the Belarusian border (Table 1, Fig. 2A). The $\mathrm{C}_{\mathrm{T}}$ values were the highest for $\mathrm{C} 40(21.45 \pm 0.00)$.

The ELISA results showed the presence of anti-ASFV antibodies in wild boar from the cases C2-C4, C6, C23, $\mathrm{C} 26, \quad \mathrm{C} 42 \quad(0.85 \pm 0.01), \quad \mathrm{C} 45 \quad(1.15 \pm 0.00), \quad \mathrm{C} 56$ $(0.26 \pm 0.00)$ and $\mathrm{C} 57$. However, these results were only confirmed by IPT in C6, C20, C23, C26, C42, and C56C57 $(0.11 \pm 0.00 ; 70 \%$ of ELISA results). Low or negative real-time PCR results were obtained in $\mathrm{C} 20$ and C26, but in contrast, these samples were serologically positive. In the case of $\mathrm{C} 42$, the high DNA concentration, with a $\mathrm{C}_{\mathrm{T}}$ value of $24.52 \pm 1.77$, was consistent with the positive results in ELISA $(0.85 \pm 0.01)$ and IPT (Table 1$)$. We found that the vast majority of cases were identified in the vicinity (within 1-10 km) of Belarusian territory (Fig. 2A), with few new ASFV cases occurring more than 11-15 km away from the Belarusian border.

The circulation of ASFV in Poland has national and international consequences for the swine trade and production, especially in the northeastern part of the country $[17,18]$. The aim of this study was to investigate the current epidemiological status of ASFV in eastern Poland. The methods used within this study included real-time PCR with a UPL as described previously by Fernaéndez-Pinero et al. [8]. The ASF real-time PCR with the UPL has been shown to be a sensitive and specific technique for the detection of ASFV. Other diagnosis techniques for ASFV include a number of real-time PCR tests $[1,18]$ and serological assays such as ELISA and IPT [16]. However, it should be noted that specific anti-ASFV antibodies are produced during the late stage of infection. In this study, we report 65 diagnosed cases of ASFV in Poland that occurred near the Belarusian national border. The analysis showed that the affected wild boar were able to migrate from 0.5 to $25 \mathrm{~km}$, but the most frequent distance was $1-10 \mathrm{~km}$. Fortunately, the virus was not detected outside the restricted area, indicating that control measures to limit wild boar reproduction have been successful. A comparison of $\mathrm{C}_{\mathrm{T}}$ values from real-time PCR assays showed a broad range of values in the context of particular cases. The presented data may be treated as a review of the virus replication cycle or age of carcasses and cannot reveal the real transmission of ASFV itself. It might be especially important in case of samples originating from carcasses of wild boar or bones. However, the comparison of different $\mathrm{C}_{\mathrm{T}}$ values obtained from the well-standardized method from different cases may at least provide reliable data on the relative concentration of viral DNA. However, due to the different kinds of samples used (bone marrow, internal organs or blood), it was difficult to provide reliable quantification of the virus in these materials. The conducted serological assays including ELISA or IPT facilitated confirmation of real-time PCR results in six ASF cases. However, material for this study was also collected from wild boar carcasses, allowing only viral DNA extraction. The number of analysed samples and ASF cases showed a peak of virus transmission between July and August but also during February and March. Between January and May 2014, analysis of material originating from 6759 wild boar revealed three positive ASFV cases. In the same season of 2015 , analysis of 4388 wild boar showed the occurrence of 29 ASFV cases. Statistical analysis at the $95 \%$ confidence level $(0.04 \%$ in 2014 and $0.66 \%$ in 2015) showed that the observed change in case number between 2014 and 2015 was significant $(p<0.05)$. These findings need to be extended for the upcoming months or years.

This study shows that ASFV transmission is not as rapid as was previously predicted $[4,16]$. However, it still presents a serious economic threat. The virus seems to be continuously transmitted in the wild boar population, but in general, the distances do not exceed $10 \mathrm{~km}$. The conducted diagnostic investigations showed that the majority of the infected wild boars died before the onset of immunity but had a high viral DNA load. This might indicate a rapid progress of wild boar ASFV infection that leads to sudden death. Two exceptions, in cases $\mathrm{C} 20$ and C26, suggest that hunted wild boars had survived the initial infection and, in spite the low or negative $\mathrm{C}_{\mathrm{T}}$ values, remained serologically positive. This could indicate the presence of naturally attenuated ASFV isolates among wild boar population. Therefore, an interesting issue for our future study will be virus isolation from wild boar showing detectable antibody titers. These isolates will be also used to inoculate experimental animals and examine their virulence.

Acknowledgments The authors acknowledge Prof. Iwona Markowska-Daniel and all technical staff of the National Reference Laboratory for Diagnosis of African Swine Fever at the NVRI. We thank MSc Anna Konarska, MSc Jolanta Kryczka, MSc Justyna Fudyma, MSc Ewa Gawęda and MSc Grzegorz Dajczer for perfect 
laboratory assistance. The study was partially supported by the project: KNOW (Leading National Research Centre) Scientific Consortium "Healthy Animal - Safe Food", decision of Ministry of Science and Higher Education No. 05-1/KNOW2/2015.

\section{Compliance with ethical standards}

Conflict of interest The authors declare that they have no competing interests.

Open Access This article is distributed under the terms of the Creative Commons Attribution 4.0 International License (http://crea tivecommons.org/licenses/by/4.0/), which permits unrestricted use, distribution, and reproduction in any medium, provided you give appropriate credit to the original author(s) and the source, provide a link to the Creative Commons license, and indicate if changes were made.

\section{References}

1. Agüero M, Fernandez J, Romero L, Mascaraque CS, Arias M, Sánchez-Vizcaíno JM (2003) Highly sensitive PCR assay for routine diagnosis of African swine fever virus in clinical samples. J Clin Microbiol 41:4431-4434

2. Arias M, Sánchez-Vizcaíno JM (2002) African swine fever eradication: the Spanish model. In: Morilla A, Jin K, Zimmerman $\mathrm{J}$ (eds) Trends in emerging viral infections of swine. Iowa State University Press, Ames, pp 133-139

3. Bastos AD, Penrith ML, Crucière C, Edrich JL, Hutchings G, Roger F, Couacy-Hymann E, R Thomson G (2003) Genotyping field strains of African swine fever virus by partial p72 gene characterization. Arch Virol 148:693-706

4. Colgrove GS, Haelterman ED, Coggins L (1969) Pathogenesis of African swine fever in young pigs. Am J Vet Res 30:1343-1359

5. Costard S, Mur L, Lubroth J, Sánchez-Vizcaíno JM, Pfeiffer DU (2013) Epidemiology of African swine fever virus. Virus Res 173:191-197

6. Diaz AV, Netherton CL, Dixon LK, Wilson AJ (2012) African swine fever virus strain Georgia 2007/1 in Ornithodoros erraticus ticks. Emerg Infect Dis 18:1026-1028

7. Fauquet CM, Mayo MA, Maniloff J, Desselberger U, Ball LA (eds) (2005) Eighth report of the International Committee on Taxonomy of Viruses. Elsevier Academic Press, London, pp 135-143

8. Fernaéndez-Pinero J, Gallardo C, Elizalde M, Robles A, Gómez C, Bishop R, Heath L, Couacy-Hymann E, Fasina FO, Pelayo V, Soler A, Arias M (2012) Molecular diagnosis of African Swine Fever by a new real-time PCR using universal probe library. Transbound Emerg Dis 60:48-58

9. Gallardo C, Fernéndez-Pinero J, Pelayo V, Gazaev I, Markowska-Daniel I, Pridotkas G, Nieto R, Fernaéndez-Pacheco P,
Bokhan S, Nevolko O, Drozhzhe Z, Pérez C, Soler A, Kolvasov D, Arias M (2014) Genetic variation among African Swine Fever Genotype II Viruses, Eastern and Central Europe. Emerg Infect Dis 20:1544-1547

10. Gallardo C, Nieto R, Soler A, Pelayo V, Fernández-Pinero J, Markowska-Daniel I, Pridotkas G, Nurmoja I, Granta R, Simón A, Pérez C, Martín E, Fernández-Pacheco P, Arias M (2015) Assessment of African swine fever diagnostic techniques as a response to the epidemic outbreaks in Eastern European Union countries. How to improve surveillance and control programmes. J Clin Microbiol. pii: JCM.00857-15

11. Gavier-Widén D, Gortázar C, Ståhl K, Neimanis AS, Rossi S, Hård av Segerstad C, Kuiken T (2015) African swine fever in wild boar in Europe: a notable challenge. Vet Rec 176:199-200

12. Gogin A, Gerasimov V, Malogolovkin A, Kolbasov D (2012) African swine fever in the North Caucasus region and the Russian Federation in years 2007-2012. Virus Res 173:198-203

13. Malogolovkin A, Yelsukova A, Gallardo C, Tsybanov S, Kolbasov D (2012) Molecular characterization of African swine fever virus isolates originating from outbreaks in the Russian Federation between 2007 and 2011. Vet Microbiol 158:415-419

14. Mur L, Igolkin A, Varentsova A, Pershin A, Remyga S, Shevchenko I, Zhukov I, Sánchez-Vizcaíno JM (2014) Detection of African swine fever antibodies in experimental and field samples from the Russian Federation: Implications for control. Transbound Emerg Dis. doi:10.1111/tbed.12304

15. Oganesyan AS, Petrova ON, Korennoy FI, Bardina NS, Gogin AE, Dudnikov SA (2013) African swine fever in the Russian Federation: spatio-temporal analysis and epidemiological overview. Virus Res 173:204-211

16. OIE Manual of Diagnostic Tests and Vaccines for Terrestrial Animals (mammals, birds and bees) (2012) African swine fever, vol 1, 7th edn. Word Organisation for Animal Health, Paris, pp 1067-1079

17. Pejsak Z, Truszczyński M, Kozak E, Markowska-Daniel I (2014) Epidemiological analysis of two first cases of African swine fever in wild boar in Poland. Med Weter 70:369-372

18. Pejsak Z, Truszczyński M, Niemczuk K, Kozak E, MarkowskaDaniel I (2014) Epidemiology of African Swine Fever in Poland since the detection of the first case. Pol J Vet Sci 17:665-672

19. Penrith ML, Vosloo Q (2009) Review of African swine fever: transmission, spread and control. J S Afr Vet Assoc 80:58-62

20. Rowlands RJ, Michaud V, Heath L, Hutchings G, Oura C, Vosloo W, Dwarka R, Onashvili T, Albina E, Dixon LK (2008) African swine fever virus isolate, Georgia, 2007. Emerg Infect Dis 14:1870-1874

21. Sánchez-Vizcaíno JM, Mur L, Gomez-Villamandos JC, Carrasco L (2015) An update on the epidemiology and pathology of African swine fever. J Comp Pathol 152:9-21

22. Sánchez-Vizcaíno JM, Mur L, Martínez-López B (2013) African swine fever (ASF): five years around Europe. Vet Microbiol $165: 45-50$ 